Als Vorsitzender des Stiftungsrats der Prof.-Lenz-Stiftung sowie des Kuratoriums Stiftungspreis "Jugend baut Europa" engagiert sich der gebürtige Hesse insbesondere für die Zusammenarbeit mit den osteuropäischen Nachbarn.

Quelle: Pressemitteilung der Jade Hochschule vom 23.7.2015.

\section{Promotion Łukasz Halik}

Am 3.6.2014 promovierte Herr kukasz Halik im Fachbereich Geowissenschaften an der Fakultät für Geographie und Geologie der Adam-Mickiewicz-Universität in Poznań, Polen, zum Thema "The graphical variables of point signs in mobile Augmented Reality system". Die Dissertation wurde betreut von Prof. Dr. Beata Medyńska-Gulij, Poznań. Gutachter waren Prof. Dr. habil. Zenon Kozieł, Toruń, und Prof. Dr.- Ing. habil. Dariusz Gotlib, Warschau.

\section{Autorenreferat}

Technological development poses new challenges for cartography. As suggested by Berlant (1996) traditional range of mapping interests should be extended by combining new types of geovisualizations which Kozieł $(2001,2003)$ calls geocompositions (geokompozycje).

According to, Gotlib (2011) a huge challenge faces cartographers in connection with imaginery known as the Augmented Reality (AR) (Caudell and Mizell 1992, Milgram and Kishino 1994, Azuma 1997). This new approach to the way of presenting spatial information, in which a key role plays public user using a mobile device. $\mathrm{He} / \mathrm{she}$ is the focal point of geovisualizations (Meng 2005). By contrast, virtual information about the spatial characteristics is displayed in the form of point signs on the screen of the mobile device as an additional layer, which is blended into the image of the real world (Feiner et al. 1997, Höllerer et al. 1999).
The most important concepts discussed in this dissertation should include primarily the concept of visual variables (Bertin 1967-1983), which can be divided into graphical variables and spatial variables. It forms the foundations of modern cartography. It is the basis of graphic design of maps, in particular point signatures. Graphic variables are a set of means of mapping expression (Żyszkowska 2000). Visual variables create signature carrying information about objects, processes or phenomena encoded by the cartographer. Not respecting the properties of these variables leads to the creation of false images from the standpoint of image perception, because you cannot then correctly answer questions relating to the overall level (Bonin 1989).

The second important element is the process of map reading, which, as described by Ratajski (1973), consists of phases: visibility, differentiation and diagnosis. The thesis describes the principles of readability associated with the limits of visual perception described by Anson and Ormelinga (1993) as: the perception threshold, the separation threshold and the differentiation threshold.

The main objective of the present dissertation is to define recommendations for the design of point signs for mobile mapping applications in the Augmented Reality system, with respect to the classical cartographic knowledge.

Thus, the author set himself the main task of verifying the following thesis:

The Augmented Reality system for mobile devices is necessary to adapt the traditional cartographic rules in specific areas of design point signs and formulate new special considerations relevant to the perception of geographical space by the user.

The specific objectives of this thesis include:

- the analysis, classification, selection and adaptation of traditional rules for the map design in relation to the specifics of visualizing

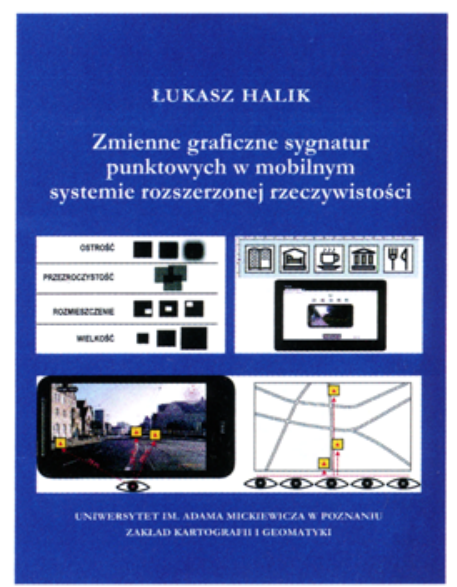

Halik, kukasz (2014): Zmienne graficzne sygnatur punktowych w mobilnym systemie rozszerzonej rzeczywistości, UAM, Poznan S. 181, ISBN: 978-83-938868-2-1

geographical space in a mobile augmented reality system;

- an attempt to determine the threshold parameters of selected visual variables building point signs in a mobile augmented reality system;

- the development of a methodology for testing the effectiveness and efficiency of selected visual variables of point signs in a mobile augmented reality system;

- the development of interactive online questionnaires to examine the geographical perception of urban space by the public user. The object of study of this dissertation are selected visual variables: size, transparency, focus and location applied to five point signs (library, hotel, cafe, museum, and restaurant). The author of this thesis analyzed their properties, such as the threshold of differentiation, effectiveness and efficiency in presenting chorological information on the screen of the mobile device (HTC Desire 3.5' $480 \times 800 p x$, Asus Transformer $10.1^{\prime} 1920 \times 1128 \mathrm{px}$ ) in Augmented Reality. The selection of the above-mentioned means of mapping expression was based on the analysis of the literature. The scientist who drew attention to the need for testing these variables, especially the variables transparency and focuswas MacEachren $(1992,1995)$. Also
Kraak and Ormeling (2010) signaled the possibility of their use in cartographic presentations using Internet technologies.

The analyzes carried out on the above-mentioned object of study are designed to supplement the observed gaps in research concerning the lack of recommendations related to the design patterns in mobile Augmented Reality system and a lack of methodology for study of the properties of graphic variables in a mobile AR system. This study and the conclusions drawn from it can be used when designing the mapping applications for mobile devices using the Augmented Reality system.

\section{- Promotion Łukasz Wielebski}

Am 3.6.2014 promovierte Łukasz Wielebski im Fachbereich Kartographie und Geomatik an der Fakultät für Geographie und Geologie der Adam-MickiewiczUniversität in Poznań, Polen, zum Thema "Cartographic Visualization of Spatial Accessibility in a Monocentric Model". Die Dissertation wurde betreut von Prof. Dr. Beata Medyńska-Gulij, Poznań, Gutachter waren Prof. Dr. Jacek Kozak, Krakau, und Prof. Dr.-Ing. Pawel Pedzich, Warschau.

The aim of the study was to determine the effectiveness and graphical attractiveness of traditional and less conventional cartographic visualization methods of spatial accessibility (both graphically simple and complex) based on a monocentric road network model. The relationships between a starting point and destination points were considered as the Euclidean distance, the road distance, and the temporal distance. For the accomplishment of the purpose put in the dissertation an original pattern of research proceedings was developed. The research procedure was based on methods of survey and empirical 